\title{
Autonomy as a Core Value of Lifelong Learning
}

\author{
Oksana A. Gavrilyuk* \\ Krasnoyarsk State Medical University \\ named after prof. V. F. Voino-Yasenetsky \\ 1 P. Zheleznyak Str., Krasnoyarsk, 660022, Russia
}

Received 16.05.2015, received in revised form 15.07.2015, accepted 22.09.2015

Implementing a new lifelong learning paradigm is hardly possible by only increasing the number of educational resources and using more information and communication technology. It should be based on promoting educational actors' critical awareness of the educational context and their autonomy. This paper reveals the potential of educational actors' autonomy as a core value of lifelong learning. It demonstrates the relevance of autonomy as an important competence of educational actors from philosophical, psychological and pedagogical perspectives. The paper proves that autonomy is beneficial for students' and teachers' personal and professional self-development, as well as for their educational and professional efficiency and psychological comfort. It emphasizes readiness for autonomy in both university teachers and students as a key factor in successful and productive use of the benefits autonomy offers for lifelong learning.

Keywords: lifelong learning, educational actors, students' autonomy, teachers' autonomy, generic competence, personal and professional self-development.

The article is written with the financial support of the European Commission within the Tempus IV programme (Project "Lifelong Language Learning University Centre Network for New Career Opportunities and Personal Development (UNICO)", № 544283-TEMPUS-1-2013-1-ES-TEMPUSJPHES).

DOI: $10.17516 / 1997-1370-2015-8-11-2283-2290$.

Research area: pedagogy.

\section{Introduction}

Nowadays, due to the increasing speed of technological change, everybody is obligated to continuously update, expand, and hone personal knowledge and skills. Staying abreast of the latest research results, new techniques and information is a prerequisite for successful work. Following this trend, the capacity of every professional to engage in lifelong learning is emphasized in many National education documents and initiatives, including Federal Education Act of 2012 and the third generation State Educational Standards.

The search for effective ways to organize lifelong education requires, on the one hand, thorough theoretical understanding of the idea of lifelong learning itself, its fundamental

(C) Siberian Federal University. All rights reserved

* Corresponding author E-mail address: Oksana.gavrilyuk@mail.ru 
bases and principles. On the other hand, this idea needs to be specified through focusing on the main educational agents: teachers and learners.

The efficiency of lifelong learning, which is known to include formal, non-formal and informal patterns of learning, is determined by a number of factors. These factors include both external, such as the extent of the provided academic freedom, the access to the latest knowledge, new resources etc., and internal ones.

Due to the pace of technological change people are offered more and more opportunities for lifelong learning available either through traditional education institutions or through online education projects. Meanwhile, the access to educational resources does not ensure the success of lifelong learning.

Life-long learning paradigm goes beyond providing access to new educational resources and technologies and requires transformation in educational actors' ways of thinking (towards creativity and critical thinking), motivation and their learning and teaching strategies.

To engage in lifelong learning a person should be ready to "innovative self-change" (Tareva, 2013). This approach seems to be concordant with Mahatma Gandhi's words "Be the change that you want to see in the world" and emphasizes internal factors of lifelong learning that should be taken into account.

While conceptualizing lifelong learning, which has become one of the major educational goals in many countries, modern education researchers claim it is concerned with promoting generic competences, necessary for adapting person's knowledge and competences to new tasks and developing new skills and competences throughout the life cycle. According to R. Smethurst, "what does not come out of the statistics is that, in order to succeed in life, in the world, in history, you need not just academic skill but personality, independence of mind, and autonomy of spirit" (Smethurst, 1995: 33).

Implementing these ideas into teaching practice, D. Nash suggests that "we teach most effectively when we help our students learn how to learn...not what to think and make and do in [the current year]; but how to think and how to learn for those years of life and profession than lie ahead" (Nash, 1994: 789). To achieve this, the researchers propose to "move away from a view of learning that is controlled outside the individual to a view of learning that is internally controlled by the individual" (Overly et al., 1980).

Being regarded as one of generic competences every professional should possess, the educational actors' autonomy is reported to involve ability of individuals to engage in learning throughout life (Key Competences for Lifelong Learning, 2007).

Following these ideas, this paper considers the autonomous educational agent as a key figure ensuring an increase of efficiency in lifelong leaning through implementation of autonomyoriented paradigm of the higher education.

\section{Educational actors' autonomy: implications for lifelong learning theory}

In a broad sociocultural context, educational actors' autonomy is regarded as "the competence to develop as a self determined, socially responsible and critically aware participant in (and beyond) educational environments, within a vision of education as (inter)personal empowerment and social transformation" (Jiménez Raya, 2007: 33).

This definition seems to be close to the philosophical interpretation of the term, which has often been associated with the ability of a man to "push the limits" or to "go over the line of the institutional culture" (Marchenko, 2013). Thus, the educational actors' autonomy based on thorough understanding of the sociocultural context may be regarded as an effective means for stimulating their vigorous activity and self- 
development both inside and outside the university environment.

Our research allowed us to specify the notion of educational actors' autonomy through revealing its strategies and associating it with desire and readiness to take control of one's own personal and professional self-development through planning, making choices and taking responsible decisions.

As we revealed, educational actors' autonomy is associated with a set of personal characteristics, including intrinsic motivation to professional achievement and personal and professional self-development, internal locus of control, responsibility, creativity, ability to goal setting, ability to decision making, ability to make choices and critical mindfulness (Gavrilyuk, 2013a: 1809). Interacting, these characteristics ensure the person's readiness for autonomous or self-directed educational activity.

To exemplify this kind of activity, it should be said that while getting new knowledge, autonomous educational actors make it relevant and valuable for them. They transform and personalize this knowledge, guided by their personal qualities and learning / working experience. Autonomy allows transformation in students' and teachers' thinking style and focuses their attention on meaningfulness of knowledge they get through asking themselves questions about what to learn, how to learn and why. Thus, autonomous students are "able to develop strategies for identifying learning issues and locating, evaluating, and learning from resources relevant to that issue" (Savery \& Duffy, 1995: 143).

There is a growing body of literature demonstrating that the notion of teacher autonomy is a necessary part of the learner autonomy concept (Little, 1995; Smith, 2000; Benson, 2010). Autonomous teachers are regarded as capable to create their own goals (Tambovkina,
2000: 63), make choices concerning one's own teaching (Aoki, 2002: 11), engage in self-directed teaching, including detachment, critical reflection, decision-making and independent action (Little, 1995) and lifelong personal and professional development (Gavrilyuk, 2013 b: 69). Teacher autonomy seems to be the most important factor promoting lifelong learning paradigm: not only is it capable to make teachers act autonomously but it can also stimulate the development of autonomy in learners.

Understanding of the role autonomy plays in lifelong learning is impossible without investigating such aspects of autonomy as provided autonomy and perceived autonomy. In the context of higher education the former involves academic freedoms of teachers and students as well as decentralization of responsibility to individual universities, teachers and students. The latter (perceived autonomy) may be represented as an attribute of university policy, as well as a teacher or student personality attribute.

Therefore, within and beyond the university educational environment, educational actors' autonomy is influenced not only by external factors (i.e., provided autonomy), but also by educational actors' internal desire and readiness for independent and responsible learning and self-development. Thus, teachers and students' readiness for autonomy is crucial because it allows (or does not allow) the teachers and students to perceive different levels of autonomy (Fig. 1).

From the psychological perspective, in the framework of the Self-determination theory, autonomy is consideredas "animportant condition, which determines psychological well-being, optimal functioning and healthy development of a personality" (Ryan \& Deci, 2006). It means that autonomy makes the process of lifelong learning inner-directed, and, consequently, desirable and enjoyable for a person. 


\begin{tabular}{|c|c|c|}
\hline $\begin{array}{c}\text { Aspects } \\
\text { of } \\
\text { autonomy }\end{array}$ & Student & Teacher \\
\hline External & $\begin{array}{c}\text { Provided } \\
\text { learner autonomy }\end{array}$ & $\begin{array}{c}\text { Provided } \\
\text { professional } \\
\text { antonomy }\end{array}$ \\
\hline \multirow[t]{2}{*}{ Internal } & & \\
\hline & $\begin{array}{l}\text { Readiness for } \\
\text { learner autonomy }\end{array}$ & $\begin{array}{l}\text { Readiness for } \\
\text { professional } \\
\text { autonomy }\end{array}$ \\
\hline \multirow{2}{*}{$\begin{array}{c}\text { External } \\
+ \\
\text { Internal }\end{array}$} & $\begin{array}{c}\text { Perceived } \\
\text { learner } \\
\text { autonomy }\end{array}$ & $\begin{array}{c}\text { Perceived } \\
\text { professional } \\
\text { autonomy }\end{array}$ \\
\hline & \multicolumn{2}{|c|}{ Perceived Autonomy } \\
\hline
\end{tabular}

Fig. 1. Aspects of educational actors' autonomy

Summarizing the above mentioned ideas, autonomous lifelong learning actors may be regarded as:

1) aware of the exterior constraints they are surrounded by;

2) able to perceive a lot of opportunities for making choice;

3) considering various stressors as stimuli for self-development;

4) intrinsically motivated to professional achievement and personal and professional selfdevelopment;

5) responsible for their own learning and professional development;

6) following proactive approach (staying ahead instead of acting reactively).

Meanwhile, the above-mentioned factors are known to be able to increase the effectiveness of personal and professional self-development. Thus, from the theoretical aspect, autonomy may be considered as one of the most important internal factors ensuring the efficiency of lifelong learning.

\section{Educational actors' autonomy: implications for lifelong learning practice}

Developing educational actors' autonomy is able to ensure creativity and diversity in lifelong learning and promote the responsibility of everyone for educational results through allowing transformation from external to internal locus of control.

Having a complex character, autonomy assumes not only a set of skills ensuring autonomous activity, but also some definite (first and foremost, democratic and hightoned) purposes and values. The study of the philosophical bases of autonomy confirms its close connection to the development of spiritual and moral potential of a person, to the understanding of the inner significance of moral standards and ethical values (I. Kant, 
N. Berdyaev, S.N. Bulgakov and others). In psychology, autonomy is also associated with individual values and meanings (A. Maslow, J. Marshall and others).

This reveals the potential autonomy has in transforming the entire system of lifelong learning organization through shifting the focus from operational aspects of educational actors' activity to its value-meaningful grounds.

Considered as a core value of lifelong learning, autonomy has a particular potential with regard to solving some axiological problems of modern education. For instance, educational actors' autonomy could help to overcome some negative aspects of the global tendency to standardization and universalization of education through providing a rational approach to introduction of innovations with respect to the national and cultural identity and specific context. E.V. Priamikova highlights the problem of commercialization of lifelong education and its transformation "into goods and services" (Priamikova, 2012: 16). Universities are now perceived by most of educational managers as business corporations where every students' and teachers' activity is evaluated according to existing educational standards. From the point of view of students universities are often considered as hypermarkets where education can be bought. This situation seems to be in contrast not only with traditionally accepted perception of universities as temples of science, but also with the principles of autonomy and democratization which form the basis of the Federal State Educational Standards, Federal Laws of the Russian Federation as well as international laws and educational initiatives. These problems could also be prevented through teachers' and students' understanding of the ideas of autonomy, which is reported as "based on universal values and the relationship between individual and collective goals" (The Bologna Process ..., 2009: 176).
Another challenge Russian education faces today is "alienation" of the rapidly developing society from the education, where the old traditions of lack of freedom, uniform curricula, collective learning and a minimum of elective courses are preserved. This alienation is manifested in the lack of both teachers and students' readiness to compete and demonstrate initiative, rationality, responsibility and independence. Meanwhile, the process of overcoming alienation is often associated with the development of internal human freedom or autonomy, which implies, first of all, a change in people's structure of values, acceptance of human responsibility, initiative, and their personal involvement in the activities within a broad sociocultural context. Acceptance of responsibility for their learning outcomes by teachers and students will ensure their "personal involvement" in the process of lifelong learning and allow them to act more consciously.

In our previous works we proved that educational actors' autonomy should be developed intentionally using autonomy oriented approach (Gavrilyuk, 2014). This approach is based on granting to students and teachers the possibility of personal participation in the organization of the educational process which should be regarded as a process of selfdevelopment. To do this it is necessary that educational actors organize their learning and their teaching in accordance with their needs and capacities, set their own objectives, develop and implement their own initiatives. According to this approach, the cornerstone of lifelong learning oriented type of the higher education should comprise two elements:

1) a complex of the interconnected, interdependent and not contradicting each other rights and opportunities given to students, teachers, and universities which take into account the responsibility of everyone for educational results (actually, the academic freedom); 
2) a "positive" (based on the sense of social responsibility) type of readiness for autonomy of teachers and students, allowing them to master certain levels of the academic autonomy.

We also identified intrinsic and extrinsic factors able to promote and impede educational actors' autonomy (Gavrilyuk \& Lakhno, 2013: 462). Based on these factors, it is possible to propose appropriate educational practices able to stimulate students' and teachers' autonomy in the university educational environment. Such practices should be based on granting students and teachers the possibility of personal involvement in the organization of their learning and professional development in accordance with their needs and abilities.

In such context, teachers and students, set their own objectives, develop and implement their own initiatives, being engaged in problem-centered educational experiences and empowered to make responsible decisions concerning their personal and professional selfdevelopment. Therefore, the implementation of this approach involves the promotion of students' and teachers' self-direction in the process of lifelong learning.

\section{Conclusion}

Lifelong learning is not about implementation of new technology or providing access to new informational resources, but about a better use of technology and a wide range of resources as a tool for adaptation to new realities and constant self-development in one's career. That is why in the ever-changing conditions of activity, it is important for a professional to gain new competences. As one of the generic competences every professional should possess, the teachers' and students' autonomy ensures their constant self-development and plays a crucial role in providing lifelong learning.

Being a core value of lifelong learning and a lifelong learning competence, educational actors' autonomy allows people to stay current in their fields and, therefore, needs to be assessed and developed in students as well as in teachers. Revealing and taking into account the level of university teachers and students autonomy can be beneficial for enhancement of practical organization of educational milieu actors' life-long personal and professional self-development on the basis of principles of freedom and democracy, declared in current Russian legislation.

\section{References}

Aoki, N. Aspects of Teacher Autonomy: Capacity, Freedom and Responsibility. Learner autonomy 7: Challenges to research and practice. Dublin, Authentik, 2002, p.110-124.

Benson, Ph. (2010). Teacher education and teacher autonomy: Creating spaces for experimentation in secondary school English language teaching. Language Teaching Research, 14(3). 259-275. doi: 10.1177/1362168810365236

Bolonskij protsess: Rezul'taty obucheniya i kompetentnostnyi podhod [The Bologna Process: Results of training and competence-based approach]. Ed. By V.I. Baydenko. Moscow, Issledovatelskii tsentr problem kachestva podgotovki spetsialistov, 2009. $536 \mathrm{p}$.

Gavrilyuk, O.A. (2013a). Understanding University Teacher Autonomy as a Mainspring of Reforming Higher Education. Journal of Siberian Federal University. Humanities \& Social Sciences, 6(12), 1800-1815.

Gavrilyuk, O.A. (2013b). Avtonomnost' sub"ektov obrazovatel'nogo protsessa kak tsennostnaya orientatsiya rossiiskogo vysshego obrazovaniya [Educational actors' autonomy as a value of Russian higher education]. V mire nauchnykh otkrytii, 3.4(39), 61-80. 
Gavrilyuk, O.A. \& Lakhno A.V. (2013). Professional Autonomy of a University Teacher in the USA and Russia: Freedom from Control or Freedom for Development? Journal of Siberian Federal University. Humanities \& Social Sciences, 6(3), 455-467.

Gavrilyuk, O.A. Normativno-pravovye aspekty issledovaniya avtonomnosti $v$ obrazovanii [Regulatory aspects of investigating autonomy in education]. Stavropol, Logos, 2014. 64 p.

Jiménez Raya, M. (2007). Developing Professional Autonomy. A Balance Between License and Responsibility. Independence, 40, 32-33.

Key Competences for Lifelong Learning. European Reference Framework. Luxembourg, Office for Official Publications of the European Communities, 2007, $12 \mathrm{p}$.

Little, D. (1995). Learning as dialogue: The dependence of learner autonomy on teacher autonomy. System, 23(2), 175-81.

Marchenko, A.N. (2013). Autonomy as the ability to output a person beyond the institutional culture. Filosofskiye nauki, 3, available at: www.online-science.ru/userfiles/file/lxopugqyumcpllfn4 niyaklyjgkpobc4.pdf

Nash, D. A. (1994). The life-long learning imperative...ends and means. Journal of Dental Education, 5(10), 785-790.

Overly, N.V., McQuigg, R.B., Silvernail, D.L. \& Coppedge, F.L. A model for lifelong learning. Bloomington, Phi Delta Kappa, 1980.

Priamikova, E.V. Competence-based approach in modern educational space: functional and structural contents. Abstract of the Doctoral Dissertation, Yekaterinburg, 2012, 38 p.

Ryan, R.M. \& Deci, E.L. (2006). Self-regulation and the problem of human autonomy. Does psychology need choice, self-determination, and will? Journal of Personality, 74, 1557-1586.

Savery, J. \& Duffy, T. Problem based learning: An instructional model and its constructivistframework. In B.G. Wilson (ed.), Constructivist learning environments: Case studies in instructional design. Englewood Cliffs, NJ, Educational Technology Publications, Inc., 1995, p.135148.

Smethurst, R. (1995). Education: a public or private good? RSA Journal, CXLIII (5465). 33-45.

Smith, R.C. Starting with Ourselves: Teacher-Learner Autonomy in Language Learning. Learner autonomy, teacher autonomy: Future directions. London: Longman, 2000, p. 89-99.

Tambovkina, T.Iu. (2000). Razvitiye professional'noi avtonomii u budushchikh uchitelei inostrannogo yazyka s ispol'zovaniem metoda proektov [Development of Professional autonomy in future foreign language teachers with the use of project method]. Inostrannye jazyki v shkole, 5, 63-65.

Tareva, E.G. Cross-cultural approach as lingvo-didactic innovation. Theory and practice of foreign languages teaching: tradition and innovation: collection of articles in memoriam of I.L. Bim. Moscow, Tezaurus, 2013, p. 61-67. 


\title{
Автономность как ведущая ценность парадигмы образования в течение жизни
}

\author{
О.А. Гаврилюк \\ Красноярский государственный медицинский университет \\ им. профессора В.Ф. Войно-Ясенецккого \\ Россия, 660022, Красноярск, ул. П. Железняка, 1
}

\begin{abstract}
Расширение спектра образовательных ресурсов и иирокое использование информацииннокоммуникационных технологий сами по себе не способны обеспечить внедрение новой парадигмы образования в течение жизни. Построение новой парадигмы должно предполагать в первую очередь стимулирование автономности субъектов образования, а также осознания и критического восприятия ими образовательного контекста. В данной статье рассмотрен потенциал автономности субъектов образования как ведущей иенности парадигмы образования в течение жизни. Продемонстрирована значимость и иенность автономности как компетентности субъектов образования в философском, психологическом и педагогическом контекстах.

B cтатье доказывается позитивное влияние автономности на процесс личностнопрофессионального саморазвития студентов и преподавателей вузов, на эффективность их деятельности и их психологическое благополучие. Выделена роль автономности как ключевого фактора, обеспечивающего использование студентами и педагогами высокого потенцииала автономии в отношении достижения цели образования в течение жизни.
\end{abstract}

Ключевые слова: образование в течение жизни, субъекты образования, автономность студентов, автономность преподавателей, ключевая компетентность, личностнопрофессиональное саморазвитие.

Статья написана при финансовой поддержке гранта программы ТЕМПУС IV Европейского Союза (проект «Создание сети университетских языковых центров для профессионального и личностного развития человека в рамках парадигмы «образование в течение всей жизни», № 544283-TEMPUS-1-2013-1-ES-TEMPUS-JPHES).

Научная специальность: 13.00.00 - педагогические науки. 